\title{
Kinetic Study of Dhatura Metal Xerophytic Medicinal Plants
}

\author{
Deepak Kumar Khare ${ }^{1 *}$, Arvind Prasad Dwivedi ${ }^{2}$, Sachin Bhatt ${ }^{1}$, M.U. Khan ${ }^{1}$ \\ ${ }^{1}$ Department of Chemistry, R.K.D.F. College, Bhopal \\ ${ }^{2}$ Department of Chemistry, Govt.S.G.S. Auto. P.G.College, Sidhi M.P.
}

*Corresponding Author: Deepak Kumar Khare, Department of Chemistry, R.K.D.F. College, Bhopal

\begin{abstract}
Based on bio-electrode potential measurement the kinetic study of Dhatura metal xerophytic medicinal plants in injured conditions have been reported. The investigation bring out the mystery of complex kinetics involved due to presence of multifunctional electric signals/action potential. The rate of reaction velocity accelerated when charge transfer of ions occur between bio-sap and Ag-Zn pair of electrodes. The role of thermodynamic parameters and activity was justified.
\end{abstract}

Keywords: Bio-transformation, charge transfer, depolarization, enhancement, randomness.

\section{INTRODUCTION}

In charak documents, ${ }^{1}$ the bio-sap of xerophytic medicinal plants, Dhatura metal L. of Acanthaceae family is treated as a toxic material, but its flower and fruits are offered to Lord Shiva in Hindu worship/mythology. The Ayurved practitioners traditionally used the extract of the plant as a medicine in treatment of a variety of diseases like cardio vascular, hyper tension, sexual aggression, mental and respiration disorder, goitre, scorpion bite etc. Its utility in medical field can't be ignored in view of their competitive values and rate of absorption. The promising results of natural products and their growing demand nationwide cannot be over looked in cosmetic industries. Ayurveda believes apparent benefits over the extract in biotransformation into pharmacoactive forms leading enhancement of bio-availability. ${ }^{2}$

The plant cells are highly sensitive bio-chemical laboratory and are excitable. The occurrence of redox reaction between bio-mass present in plants and surface of materials lead transient depolarization of cell membranes. The ions of tissues associated with electromagnetic waves ${ }^{3}$ give rise action bio electrode potential ${ }^{4}$ (BEP), this may be an additional source of extraction of nonconventional energy from xerophytic medicinal plants that last for a long time. For last two decades, few electrochemists using an idea of BEP, explored the kinetics and pharmacokinetic studies of the medicinal plants like Oupuntia coccinellifera ${ }^{4}$ Euphorbianeriifolia $^{4}$, calotropisprocera ${ }^{5}$, Coleusamboinicus $^{6}$, gigantea ${ }^{7}$, Rauwolfia $^{8}$ serpentina, and more recently Hibiscus Rosa-sinenses$\mathrm{L}^{9}$ employing different pairs of electrodes in different seasons respectively. Inspired from naturophillic facts of desert plants, this prompted authors to study the kinetics of the Dhatura metal medicinal plants hither to unreported results, as kinetics work on this topic was scanty and rare hence aimed to investigate it.

\section{EXPERIMENTAL}

All chemicals used in this probe were of analytical grade. The three types of Dhatura metal xerophytic plants abbreviated as $\mathrm{DT}^{1}, \mathrm{DT}^{2}$, and DT3 were chosen for the kinetic investigation. The medicinal plants are mostly found in desert and mostly grown in tropical regions all over India. It contains flowers and fruits that find vast and wide applications in medical fields. The fresh leaves of the plants are plucked, treated with acetone; epidermis was removed gently and cut into size to get smooth contact with dimension of employed electrodes. The injured leaf in vitro conditions is kept between the electrodes to construct bio-electrode device (BED). The kinetic studies were carried out by direct measurement of bio-electrode potential, through highly accurate digital panel meter at 8 hours intervals of time. The entire investigation was performed at four different temperatures in winter, summer, and Rainy seasons. The BEP measurement based kinetic data was edited before feeding to equation of integration method for evaluation of rate constant. The reaction velocity was also ascertained by graphical and least square method within precision of an error $\pm 3 \%$. 


\section{RESULTS AND DISCUSSION}

The xerophytic plants by virtue of storing a lot of energy become ultimately a source of ionic potentials which is main base of measurement of rate constant. The observed kinetic data of Dhatura metal medicinal plants have been collected in three different seasons. One such exemplary of DT 1 as a representative set of observation has been demonstrated in Table 1. The plot of log a/ (a-x) versus time graph yielded a straight line passing through origin with an approximately unit slope (Fig.1).

Table1. Kinetics of xerophytic medicinal plant Dhatura metal (DT1)

Medicinal plant : Dhatura metal (DT1)

Electrode pair : Ag-Zn

Season : Winter

Temperature : $292 \mathrm{~K}$

\begin{tabular}{|l|c|c|c|}
\hline S. No. & $\begin{array}{c}10^{2} \times \text { Time } \\
(\mathrm{sec} .)\end{array}$ & $\begin{array}{c}\text { Bio-electrode potential (BEP) } \\
(\text { milli volt })\end{array}$ & $\left.10^{6} \times \mathrm{k}^{-1}\right)$ \\
\hline 1. & 0 & 1683 & - \\
\hline 2. & 288 & 1411 & 6.12 \\
\hline 3. & 576 & 1210 & 5.72 \\
\hline 4. & 864 & 978 & 6.28 \\
\hline 5. & 1152 & 863 & 5.79 \\
\hline 6. & 1440 & 670 & 6.39 \\
\hline 7. & 1728 & 566 & 6.30 \\
\hline 8. & 2016 & 485 & 6.17 \\
\hline 9. & 2304 & 423 & 5.99 \\
\hline
\end{tabular}

Average $\mathrm{k}=6.09 \times 10^{-6}\left(\mathrm{~s}^{-1}\right)$

Graphical $\mathrm{k}=5.97 \times 10^{-6}\left(\mathrm{~s}^{-1}\right)$

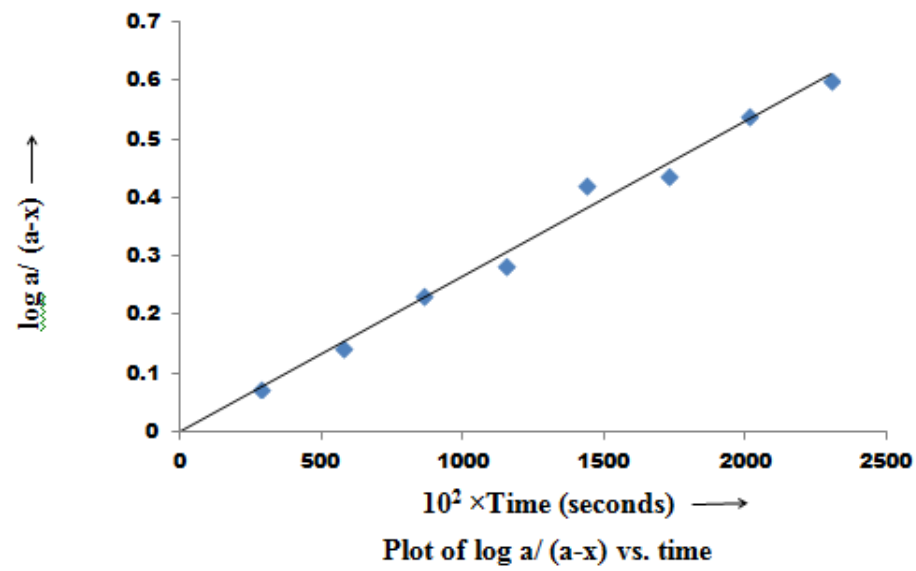

Fig1. Medicinal plant: Dhatura metal (DT1); Electrode pair: Ag-Zn; Season: Winter;

Table2. Thermodynamic and Activation parameters

\begin{tabular}{|c|c|c|c|c|c|c|}
\hline $\begin{array}{c}\text { S. } \\
\text { No. }\end{array}$ & $\begin{array}{c}\text { Xerophytic } \\
\text { medicinal plants }\end{array}$ & Season & $\begin{array}{c}\mathbf{E a} \\
(\mathbf{k J})\end{array}$ & $\begin{array}{c}\Delta \mathbf{H}^{\#} \\
(\mathbf{k J})\end{array}$ & $\begin{array}{c}\Delta \mathbf{G}^{\#} \\
(\mathbf{k J})\end{array}$ & $\begin{array}{c}-\Delta \mathbf{S}^{\#} \\
\left(\mathbf{J K}^{-1}\right)\end{array}$ \\
\hline 1. & $\begin{array}{c}\text { Dhatura metal } \\
\left(\mathrm{DT}_{1}\right)\end{array}$ & Winter & 7.38 & 4.77 & 100.68 & 328.44 \\
\hline 2. & $\begin{array}{c}\text { Dhatura metal } \\
\left(\mathrm{DT}_{2}\right)\end{array}$ & Summer & 6.84 & 3.62 & 106.48 & 335.04 \\
\hline 3. & $\begin{array}{c}\text { Dhatura metal } \\
\left(\mathrm{DT}_{3}\right)\end{array}$ & Rainy & 10.54 & 5.89 & 102.51 & 323.53 \\
\hline
\end{tabular}

The studies reveal that the medicinal plants under probe obey first-order upto 64 hours and showing complex kinetics beyond it, declined towards fractional-order. The addition of different $\left[\mathrm{CuSO}_{4} .5 \mathrm{H}_{2} \mathrm{O}\right]$ slowed down the physiological activities, photo synthesis due to deactivation of tissues of bio-sap consequently showing decreasing trend in BEP and rate. The respiratory substrate glucose exhibited maximum rate in morning of summer rather than rest of the two seasons winter and rainy and rate becomes static in the specified time. The added monovalent cations : $\mathrm{Na}+$ and $\mathrm{K}+$ and 
anion $\mathrm{Cl}^{-}$more rapidly enters in mesophyll cell10 than di- and trivalent ions generate more BEP which leads proportionally more reaction velocity due to more ionic contribution. ${ }^{11}$ The variation of temperatures on reaction rate was studied in different seasons viz. Winter $\left(14,19\right.$ and $\left.24^{\circ} \mathrm{C}\right)$, Summer $\left(29,34\right.$ and $\left.39^{\circ} \mathrm{C}\right)$, and Rainy $\left(22,25\right.$ and $\left.30^{\circ} \mathrm{C}\right)$ respectively and activation parameters evaluated are shown in Table 2. There are numerous factors operative in mechanism such as $\mathrm{pH}$, conductivity, age of plant cells, ionic transport, chloroplast, charge transfer reactions etc. The study reveals that a biocell is constructed between waxy substrates deposited around the site of injured surface of medicinal plants and electrodes used in sandwiched condition.

The concentration of tissues in injured site varies as a function of potential. The concept of an electrical double layer formation of oppositely charged ions and dominancy of breaking of dipolar Zwitter ions of amino acids in the cell leads the measurement of BEP which in turn rate constant. The mechanism and related rate law is analogous to as postulated by earlier electrochemists.4-9

The sequence of activity derived for medicinal plants under investigation in three seasons based on rate measurement was found in the following order:

DT2 (summer) >DT1 (winter) >DT3 (Rainy)

The above order of reactivity is also supported by simultaneous occurring of enzymatic reactions in increased number of cells. The cells tend to attain the state of thermodynamic equilibrium. Overall randomness was observed in the system during the study due to occurrence of oscillatory reactions which is measured in light of entropy of activation $(\triangle \mathrm{S} \#=-323.53$ to $-335.04 \mathrm{JK}-1)$. The Gibbs free energy $(\Delta \mathrm{G} \#)$ values lie between 100.68 to $106.48 \mathrm{~kJ}$, approximately very close to each other. This concludes that identical pattern of mechanism is followed by the medicinal plants. Summing up above facts by and large, the reactions occurring are enthalpy controlled.

\section{CONCLUSION}

The kinetic studies of xerophytic medicinal plants were conducted based on BEP in three seasons. Various thermodynamic parameters were determined. The order of activity was explained. The study is very useful in extraction of drugs and in the field of extraction of conventional energy.

\section{REFERENCES}

[1] Acharya, BalKrishna : Ayurved Herbals Mystery, Divya Publication. Patanjali Haridwar, 2008, 5th Edn. 172-175.

[2] Shephered, V.A., Current Science, 1999, 77(1), 189-195.

[3] Bose, J.C., The Nervous Mechanism of Plants, Longmans, Green and Co, London, 1926.

[4] Sarabhai, P., Khan, M.U., Nigam, S.K. and Agarwal, R., J. Chem. France, 2007, 2C, No. 06386.

[5] Singh, P.K., Agrawal, R., Khan, M.U., Nigam, S.K., and Khan, Shahnaz : Asian J. Chem. 2007, 19, 213.

[6] Saket, S.S, and Dwivedi, H.P., Proc. 47th Annual Convention of Chemists and International conference on Recent Advances in Chemical Science, Raipur, 2010.

[7] Swami, M.N., Nagmani Manikpuri : Elect. J. Adv. Research, 2015, 1(II), 114-119.

[8] Bunkar, Alka Rani, Int. J. Chemical Studies, 2016, 4(6), 102-104.

[9] Bhawna Pandey, Nigam, S.K., Parihar, S.S. and Dwivedi, Arvind Prasad, Intl. J. Adv. Research in Chemical Science (IJARCS), 2018, 5, (5), pp.15-19.

[10] Bhakani, D.S., J. Some Aspect of Aromatic and Medicinal Plants, 1997, 74, 5.

[11] Kolawole, J.A., and Moduenyi, A., Eur. J. Drug, Metab. Pharmacokinetic, 2004, 29(1), 25-29.

Citation: Deepak Kumar Khare1, et.al. "Kinetic Study of Dhatura Metal Xerophytic Medicinal Plants". International Journal of Advanced Research in Chemical Science (IJARCS), 6(5), pp. 19-21, DOI:http://dx.doi.org/10.20431/2349-0403.0605004

Copyright: () 2019 Authors. This is an open-access article distributed under the terms of the Creative Commons Attribution License, which permits unrestricted use, distribution, and reproduction in any medium, provided the original author and source are credited. 